\title{
Laminarin (Beta-glucan) of Brown Algae Sargassum mcclurei: Extraction, Antioxidant Activity, Lipoxygenase Inhibition Activity, and Physicochemistry Properties
}

\author{
Dang Xuan Cuong \\ Organic Matterial from Marine Resource, Nhatrang Institute of Technology Application and Research, Vietnam Academic of Science and \\ Technology, Nha Trang, Vietnam
}

Email address:

cuong_mails@yahoo.com.vn

\section{To cite this article:}

Dang Xuan Cuong. Laminarin (Beta-glucan) of Brown Algae Sargassum mcclurei: Extraction, Antioxidant Activity, Lipoxygenase Inhibition Activity, and Physicochemistry Properties. World Journal of Food Science and Technology. Special Issue: Marine Bio-Polymer: Bio-Activity, Extraction and Application. Vol. 4, No. 1, 2020, pp. 31-39. doi: 10.11648/j.wjfst.20200401.15

Received: March 17, 2020; Accepted: April 2, 2020; Published: April 29, 2020

\begin{abstract}
Laminarin is a storage glucan found in almost brown algae and possesses value bioactive. The study focused on the effect of the input factors of the extraction such as the temperature $\left(30,50,70\right.$, and $\left.90^{\circ} \mathrm{C}\right)$, the time $(01,02,03$, and 04 hours), the aqueous to algae ratio $(20 / 1,30 / 1,40 / 1$, and $50 / 1(\mathrm{v} / \mathrm{w}))$, and solvent $\mathrm{pH}(2,7$, and 9$)$ on the function targets (laminarin content, total antioxidant activity, reducing power activity, and lipoxygenase inhibition activity), and the physical chemistry characterization of highest laminarin content was analyzed. The results showed the temperature, the time, the aqueous to algae, solvent $\mathrm{pH}$ affected on laminarin content, total antioxidant activity, reducing power activity, and lipoxygenase inhibition activity that got the highest value of $11.98 \pm 0.49 \mathrm{mg}$ laminarin equivalent/g DW, $19.66 \pm 0.47 \mathrm{mg}$ ascorbic acid equivalent/g DW, $15.55 \pm 0.61 \mathrm{mg} \mathrm{FeSO}{ }_{4}$ equivalent/g DW, and $73.04 \pm 2.53 \mu \mathrm{M}$ linoleic acid equivalent $/ \mathrm{g} \mathrm{DW}$, respectively. The suitable condition of extraction was collected consisting of the temperature of $90^{\circ} \mathrm{C}$ for 2 hours with the solvent to algae ratio of $40 / 1(\mathrm{v} / \mathrm{w})$ in $\mathrm{pH}$ solvent of 7. The average molecular weight, viscosity, and sulfate content of laminarin was $505.18 \mathrm{kDa}, 14,17 \pm 0.29 \mathrm{cPs}$, and $48.72 \%$, respectively. FTIR spectrum exhibited function groups of laminarin composed of $\mathrm{O}-\mathrm{H},-\mathrm{CH}_{2}^{-}, \mathrm{C}=\mathrm{O}, \mathrm{C}-\mathrm{O},-\mathrm{C}-\mathrm{H}$, $-\mathrm{O}-\mathrm{SO}_{3}^{-}$, and $-\mathrm{CH}=\mathrm{CH}-(\mathrm{cis})$.
\end{abstract}

Keywords: Antioxidant, Extraction, Laminarin, Lipoxygenase, Molecular, Viscosity

\section{Introduction}

Laminarins are polysaccharides belong to storage glucans of almost brown algae consisting of glucose units with the linkages of $\beta(1-3)$ and $\beta(1-6)$ in a linear chain and branch chain, respectively [1]. Laminarin exists in brown algae according to the forms of soluble and insoluble in water, and the soluble mainly depends on the level of branching in their structure. The structure and content of laminarin are different in each algae species, varies from 0.03 to $6.24 \%$ on a dry weight basis $[1 ; 2]$, for example, Pelvetia canaliculata (0.03\%) [2], Ascophyllum nodosum (5.82\%), Laminaria hyperborea (6.24\%) [1]. Laminarin content also depends on seasons and habitation of brown algae, such as existing in Ireland [1], not in Germany [2], compared in Ascophyllum nodosum. Laminarin content of twelve brown algae species in Germany varies from 0.03 to $0.86 \%$ on a dry weight basis, except for three species (Cystoseira tamariscifolia, Ascophyllum nodosum, and Halidrys siliquosa) do not contain laminarin [2]. The structure and the content of laminarin decide its bioactive, for example, molecular structure, branch numbers, branch length, and monosaccharide compositions. Almost studies show that laminarin possesses the activity of antioxidant [2], antibacterial [1], anti-resistance to chemical [3], anticancer [4], antitumor [5], and antioxidant activity is interesting more. Almost studies show the content, bioactivity, and structure of laminarin extracting from brown algae in the temperate zone and frigid zone, not tropical zone. The previous studies do not notice on laminarin in brown algae Vietnamese. Species Sargassum mcclurei found commonly grown in Vietnam, they are evaluated as a bioactive substance resource and used 
as a medicinal plant for a traditional medicine. Thus, the study focused on the extraction of laminarin from brown algae Sargassum mcclurei and the evaluation of their bioactive (antioxidant activity, and enzyme lipoxygenase inhibition) and chemical composition.

\section{Material and Methods}

\subsection{Material}

Brown algae $S$. mcclurei found commonly grown in Central South of Vietnam, collected in April 2017, cleaned by using the seawater, and transported to the laboratory under $10^{\circ} \mathrm{C}$. They were dried until the moisture of $19 \pm 1 \%$, ground, and stored in the dark condition at $15^{\circ} \mathrm{C}$ for further studies.

\subsection{Sample Preparation}

Brown algae was soaked in aqueous with the aqueous to brown algae ratio $(20 / 1,30 / 1,40 / 1$, and $50 / 1(\mathrm{v} / \mathrm{w}))$ in $\mathrm{pH}(2,7$, and 10$)$ for the time $(60,120,180$, and 240 minutes $)$ at various temperatures $\left(30^{\circ} \mathrm{C}, 50^{\circ} \mathrm{C}, 70^{\circ} \mathrm{C}\right.$, and $\left.90^{\circ} \mathrm{C}\right)$. After extraction, the supernatant was collected through the membrane Whatman No. 4 and precipitating laminarin by $80 \%$ ethanol. The residues (laminarin) were cleaned by $80 \%$ ethanol twice and dried for further studies. The experiment design of extraction was according to the method of a run factor and other fixed factors. To evaluate the target functions such as laminarin content, antioxidant activity (total antioxidant, and reducing power), and enzyme lipogenxynase inhibition, $01 \mathrm{~g}$ of laminarin was dissolved into 50 water and filtered for further studies, and the analysis of chemical composition and viscosity on the highest antioxidant laminarin.

\subsection{Determination of Laminarin Content}

Laminarin content was quantified basing on the measurement of the released glucose content after laminarin hydrolysis by the enzyme. $100 \mu \mathrm{L}$ of the sample added to 100 $\mu \mathrm{L}$ of the enzyme $\beta$-glucosidase and kept for $15 \mathrm{~min}$ at $40^{\circ} \mathrm{C}$, and added to $03 \mathrm{~mL}$ of GOPOD (glucose oxidase/peroxidase) reagent and incubated at $40^{\circ} \mathrm{C}$ for $20 \mathrm{~min}$ for measuring the absorbance at $510 \mathrm{~nm}$ with laminarin standard from Laminaria digitata [6].

\subsection{Evaluation of Biological Activity}

\subsubsection{Evaluation of Total Antioxidant Activity}

Total antioxidant activity was determined to base on the color formation of $\mathrm{Mo}^{5+}$ and measured at the wavelength of $695 \mathrm{~nm}$ with ascorbic acid standard as the description in [7].

\subsubsection{Evaluation of Reducing Power Activity}

Reducing power activity was evaluated to base on the measurement of color formation of $\mathrm{Fe}^{2+}$ at the wavelength of $655 \mathrm{~nm}$ with $\mathrm{FeSO}_{4}$ standard as in [8].

\subsubsection{Evaluation of Lipoxygenase Inhibition Activity}

The reaction mixture contained $0.2 \mathrm{M}$ citrate-phosphate buffer $\mathrm{pH}-9.0,0.25 \%$ Tween 20, 0.125mM linoleic acid, an enzyme solution $(57 \mu \mathrm{g}$ protein) and $10 \mu \mathrm{L}$ algal extract to a final volume of $1 \mathrm{ml} .10 \mu \mathrm{L}$ of aqueous or ethanol was used instead of the extract as a control. The enzyme reaction was carried out in the cuvette and monitored at $234 \mathrm{~nm}$ until the reaction rate reached a steady state. This wavelength corresponds to the absorption of the hydroperoxides generated by the action of the lipoxygenase on linoleic acid. The percentage inhibition defined by the rate of increase in OD in the absence of algal extract to that measured with the extract [9].

\subsection{Determination of Physicochemistry Properties}

Molecular weight and fragmentation of laminarin were determined to base on the machine of LC/MS with static phase (Eclipse XDB-C8 $5 \mu \mathrm{m}, 4.6 \times 150 \mathrm{~mm}$ (Agilent)) and a mobile phase (acetonitrile, deion water ((Pure Water System, WP 710), both acetonitrile and deion water composed of $0.1 \%$ of formic acid). The gradient of acetonitrile was from $10 \%$ to $90 \%$ for 20 minutes.

The viscosity determination of laminarin was by using the dissolve of $05 \mathrm{~g}$ of laminarin powder into $495 \mathrm{~g}$ of aqueous and keeping at $29^{\circ} \mathrm{C}$ for the viscosity measurement at the rate of $100 \mathrm{rpm}$.

The analysis of the FTIR spectrum was on the machine Tensor 37 (Brucker, Germany). The spectrum range of 7,500 to $370 \mathrm{~cm}^{-1}$ with beamsplitter of standard $\mathrm{KBr}$; the extended spectral range of 15,000 to $370 \mathrm{~cm}^{-1}$ with a near and middle infrared detector.

The content of sulfate was quantified according to the $\mathrm{BaCl}_{2}$-gelatin turbidity method, as in [10], based on the absorbance measurement of the released barium sulfate at $\lambda=360 \mathrm{~nm}$ with potassium sulfate as standard

\subsection{Data Analysis}

All experiments were in triplication $(n=3)$. Statistic analysis was by using the software MS. Excel 2010.

\section{Resuls and Discussion}

\subsection{Effect of Extraction Condition}

\subsubsection{Effect of Extracting Temperature}

Extraction temperature affected strongly laminarin content $(\mathrm{p}<0.05)$, antioxidant activity $(\mathrm{p}<0.05)$, and lipoxygenase inhibition $(\mathrm{p}<0.05)$. Laminarin content varied from $1.17 \pm 0.04$ to $8.49 \pm 0.38 \mathrm{mg}$ laminarin equivalent $/ \mathrm{g} \mathrm{DW}$ and got the average value of $5.25 \pm 0.25 \mathrm{mg}$ laminarin equivalent $/ \mathrm{g} \mathrm{DW}$. Total antioxidant activity and reducing power activity was in the range of $2.72 \pm 0.22$ and $13.1 \pm 0.4 \mathrm{mg}$ ascorbic acid equivalent/g DW (Figure 1), and 2.66 \pm 0.09 and $12.6 \pm 0.34 \mathrm{mg}$ $\mathrm{FeSO}_{4}$ equivalent/g DW (Figure 2), respectively. Lipoxygenase inhibition activity got the value from $51.18 \pm 1.28$ to $71.77 \pm 1.93 \mu \mathrm{M}$ linoleic acid equivalent/g DW (Figure 2). Laminarin content, total antioxidant activity, reducing power, and lipoxygenase inhibition activity got the highest value in $90^{\circ} \mathrm{C}$ and increased following the increase of extraction temperature. The average increase in laminarin 
content and total antioxidant activity was 2.1 and 1.77 times after the extraction temperature increased to $20^{\circ} \mathrm{C}$, corresponding to $2.44 \mathrm{mg}$ laminarin equivalent/g DW and $3.46 \mathrm{mg}$ ascorbic acid equivalent/g DW. Reducing power activity and inhibition of enzyme lipoxygenase was the average increase of 1.76 and 1.12 times, corresponding to 3.31 $\mathrm{mg} \mathrm{FeSO}_{4} / \mathrm{g} \mathrm{DW}$ and $6.86 \mu \mathrm{M}$ linoleic acid equivalent/g DW after the increase of extraction temperature was $20^{\circ} \mathrm{C}$. The control of extraction temperature help to the control of laminarin content, antioxidant activity, and enzyme lipoxygenase inhibition activity extracting from species $S$. mcclurei. The extracting temperature in the current study was different from the notice of Spicer et al. [11] on the extraction of laminarin at $40^{\circ} \mathrm{C}$ under reduced pressure.

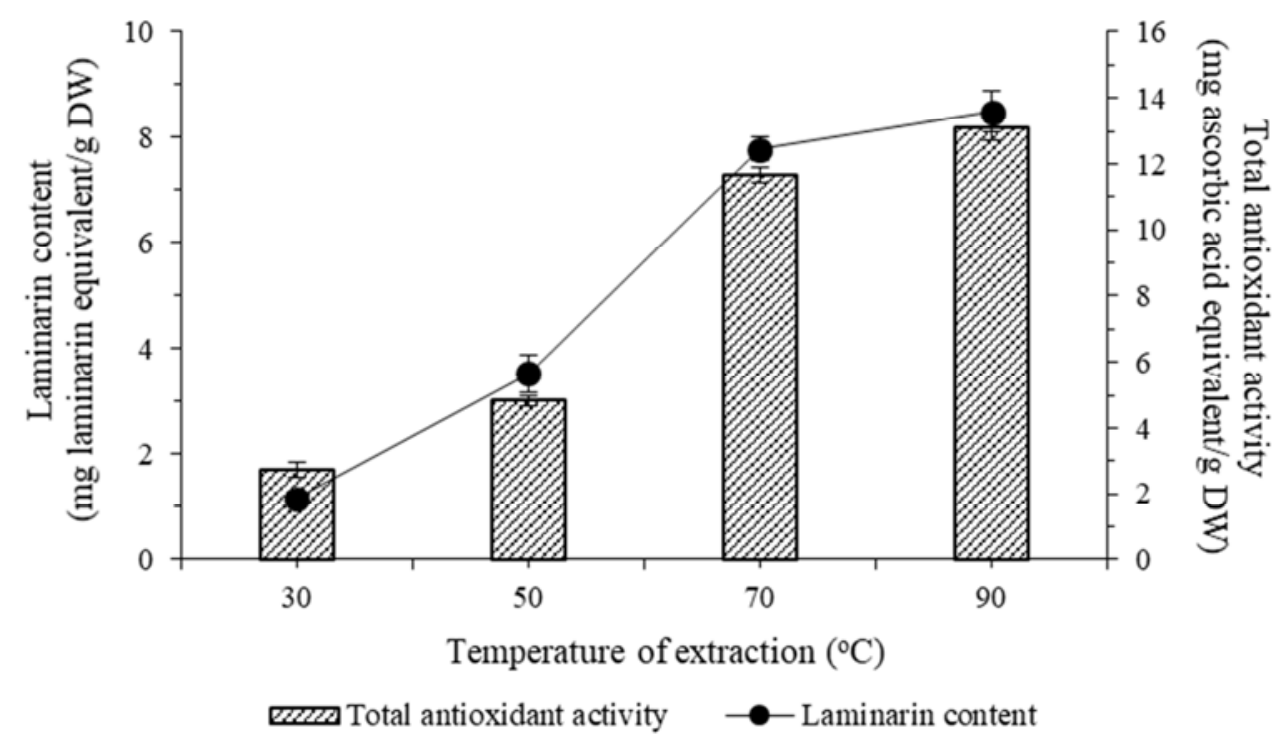

Figure 1. Effect of extracting temperature on laminarin content and total antioxidant activity.

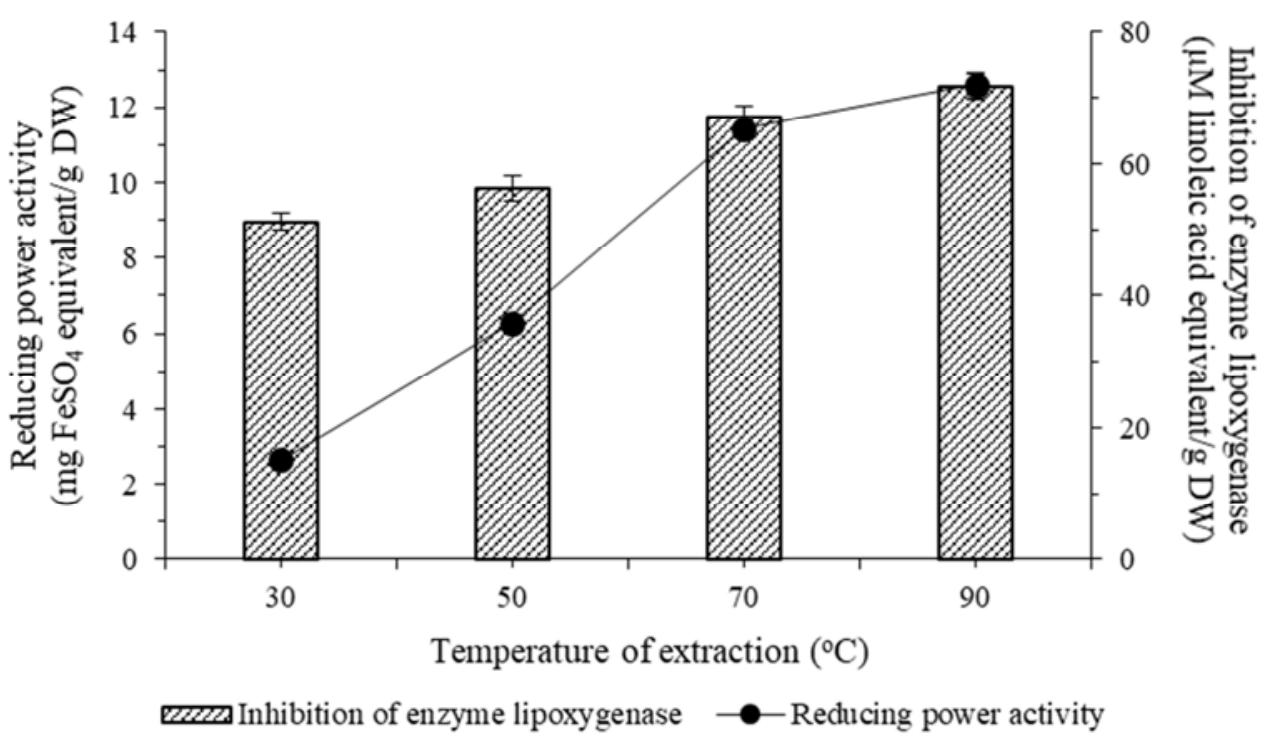

Figure 2. Effect of extracting temperature on reducing power activity and lipoxygenase enzyme inhibition activity.

\subsubsection{Effect of Extracting Time}

Laminarin content, antioxidant activity, and lipoxygenase inhibition activity were strongly impacted by the time of extraction and changed the increasing trend according to the extraction time $(\mathrm{p}<0.05)$. Laminarin content increased from $8.49 \pm 0.38$ to $10.58 \pm 0.57 \mathrm{mg}$ laminarin equivalent $/ \mathrm{g} \mathrm{DW}$, corresponding to $19.75 \%$ in comparison to the highest laminarin content that occurred in the extracting time of 4 hours (Figure 3 ). Laminarin content increased by $13.04 \%$ for the extracting time of 2 hours, compared to 1 hour. The significant difference in laminarin content only occurred when the extracting time was from 0 to 2 hours. Total antioxidant and reducing power activity varied from $13.10 \pm 0.4$ to $17.33 \pm 0.39 \mathrm{mg}$ ascorbic acid equivalent $/ \mathrm{g} \mathrm{DW}$ (Figure 3) and $12.60 \pm 0.34$ to $15.24 \pm 0.41 \mathrm{mg} \mathrm{FeSO}_{4}$ equivalent/g DW and got the average value of $16.07 \pm 0.35 \mathrm{mg}$ 
ascorbic acid equivalent/g DW and $14.42 \pm 0.37 \mathrm{mg} \mathrm{FeSO}{ }_{4}$ equivalent/g DW (Figure 4), respectively. Lipoxygenase inhibition activity got the highest value of $77.02 \pm 2.34 \mu \mathrm{M}$ linoleic acid equivalent/g DW at the extraction time of 4 hours and was 1.07 times in comparison to the extraction time of 01 hours. Laminarin content, total antioxidant activity, reducing power, and lipoxygenase inhibition activity got the highest value at the extraction time of 04 hours, but the difference in a statistic significance occurred for the extraction time of 2,3 , and 4 hours.

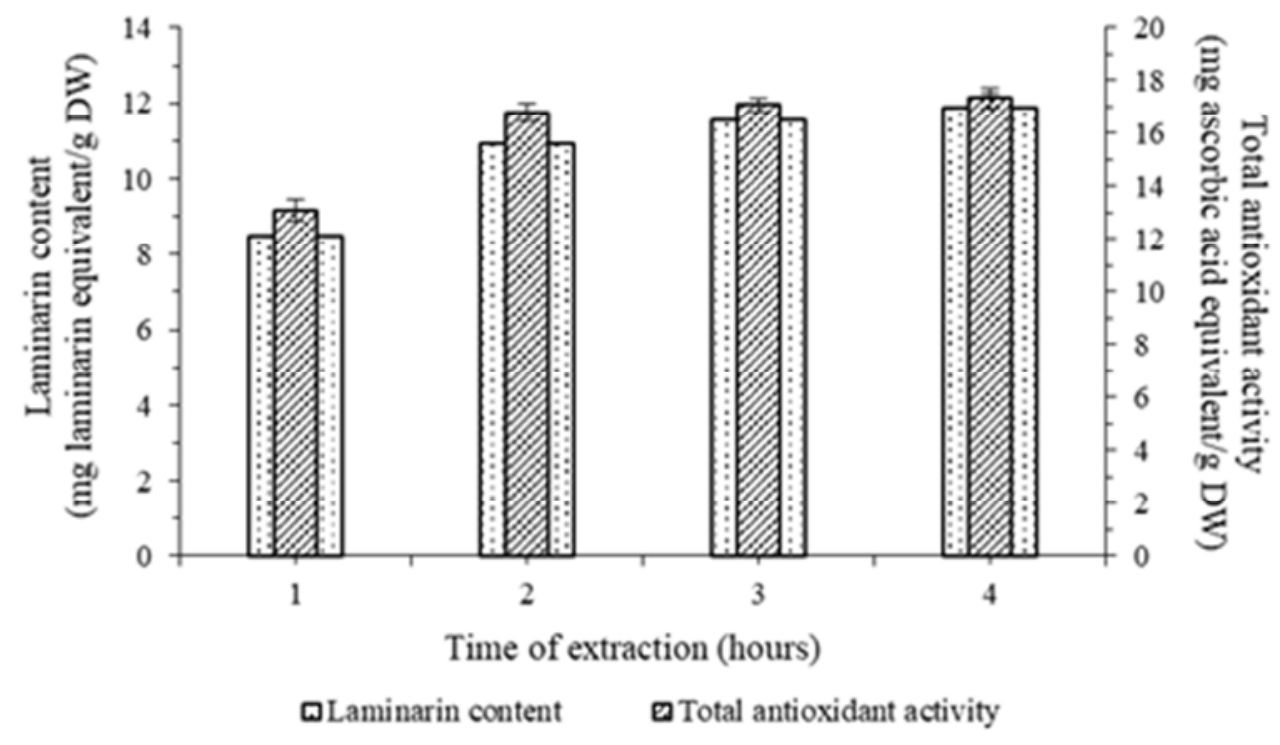

Figure 3. Effect of extracting time on laminarin content and total antioxidant activity.

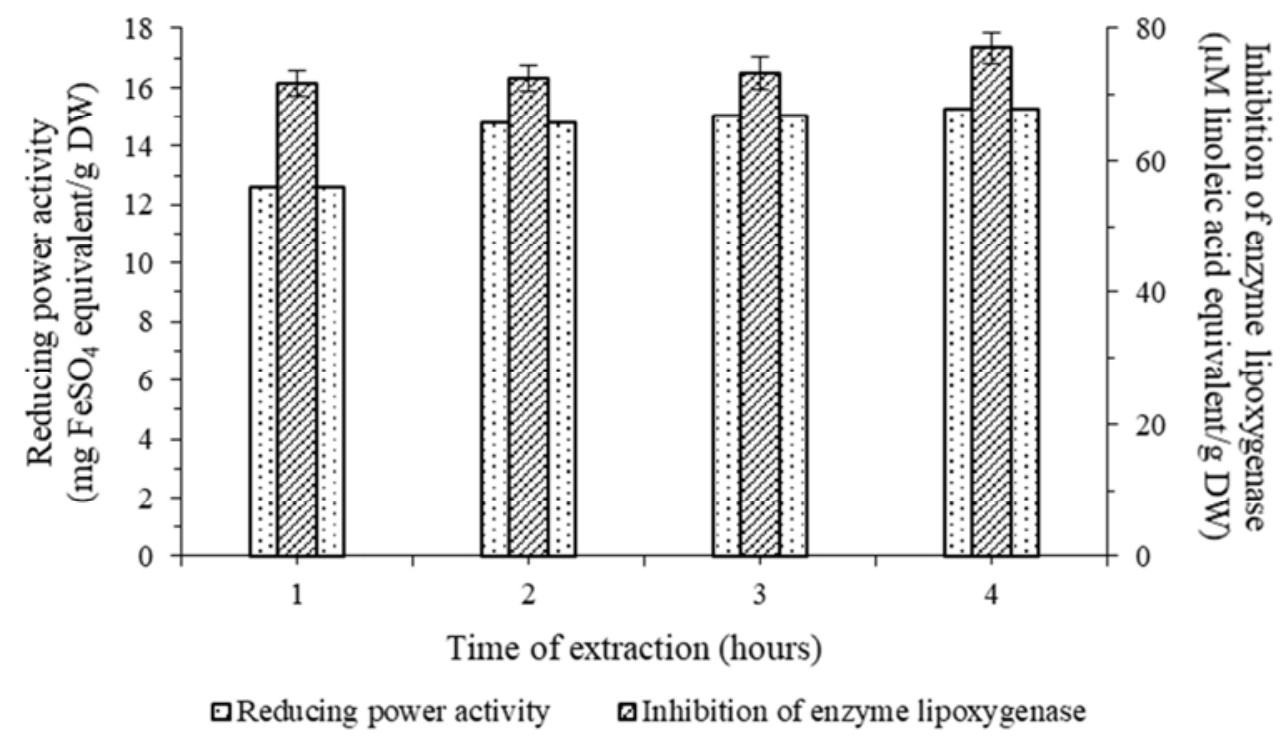

Figure 4. Effect of extracting time on reducing power activity and lipoxygenase enzyme inhibition activity.

\subsubsection{Effect of the Solvent to Algae Ratio}

The solvent to algae ratio affected laminarin content, total antioxidant activity, reducing power activity, and lipoxygenase inhibition activity $(\mathrm{p}<0.05)$ that got the highest value of $11.98 \pm 0.49 \mathrm{mg}$ laminarin equivalent $/ \mathrm{g} \mathrm{DW}$, $19.66 \pm 0.47 \mathrm{mg}$ ascorbic acid equivalent/g DW (Figure 5), $15.55 \pm 0.61 \mathrm{mg} \mathrm{FeSO}{ }_{4}$ equivalent/g DW, and $73.04 \pm 2.53 \mu \mathrm{M}$ linoleic acid equivalent/g DW (Figure 6) at the aqueous to algae ratio of $50 / 1(\mathrm{v} / \mathrm{w})$. The difference in laminarin content, antioxidant activity, and lipoxygenase inhibition activity did not occur at the aqueous to algae ratio from $40 / 1$ to $50 / 1(\mathrm{v} / \mathrm{w})$ $(\mathrm{p}>0.05)$ but occurred between the aqueous to algae ratio of $30 / 1$ and $50 / 1(\mathrm{v} / \mathrm{w})$. The laminarin content, total antioxidant activity, reducing power activity, and lipoxygenase inhibition activity at the aqueous to algae ratio of $20 / 1(\mathrm{v} / \mathrm{w})$ was $71.53 \%, 72.69 \%, 53.19 \%$, and $80.32 \%$, compared to the aqueous to algae ratio of $50 / 1(\mathrm{v} / \mathrm{w})$, respectively, and was $0.78,0.85,0.84$, and 0.91 times in comparison to the aqueous to algae ratio of $30 / 1(\mathrm{v} / \mathrm{w})$. The solvent to algae ratio in the current study was different from the review notice of 
SheKhar [1].

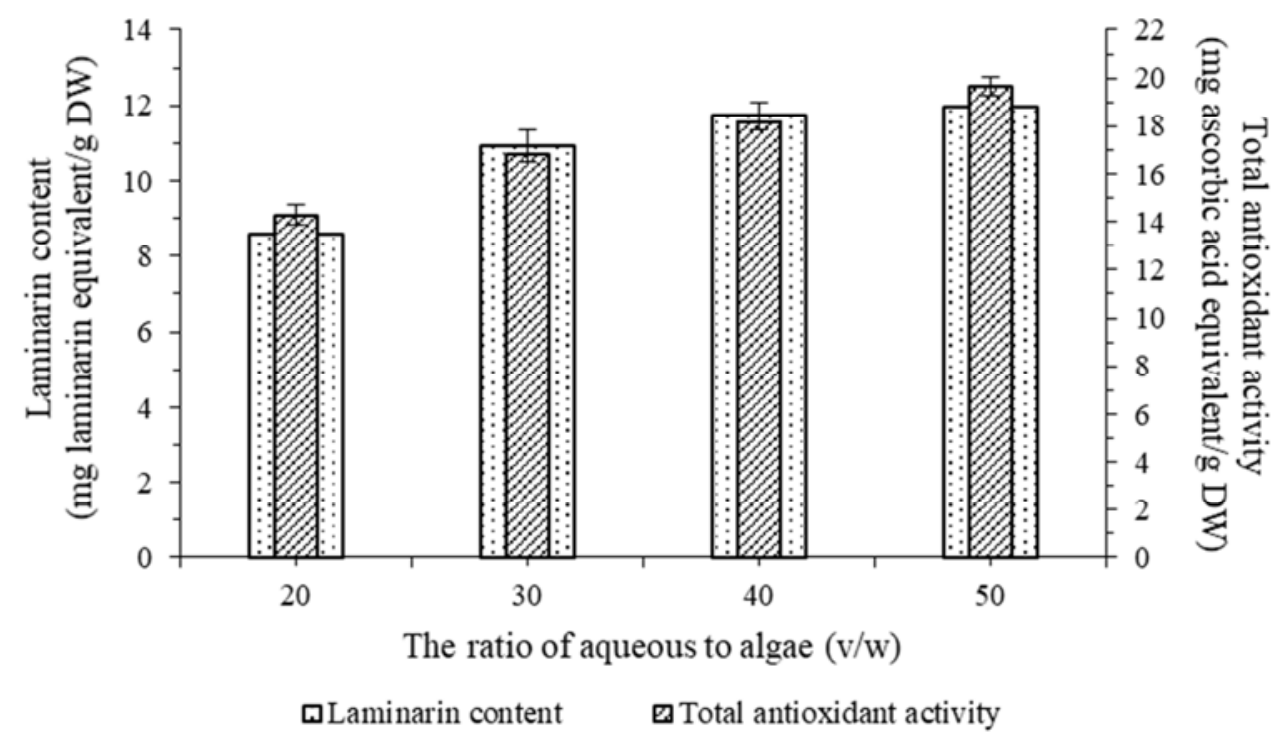

Figure 5. Effect of the solvent to algae ratio on laminarin content and total antioxidant activity.

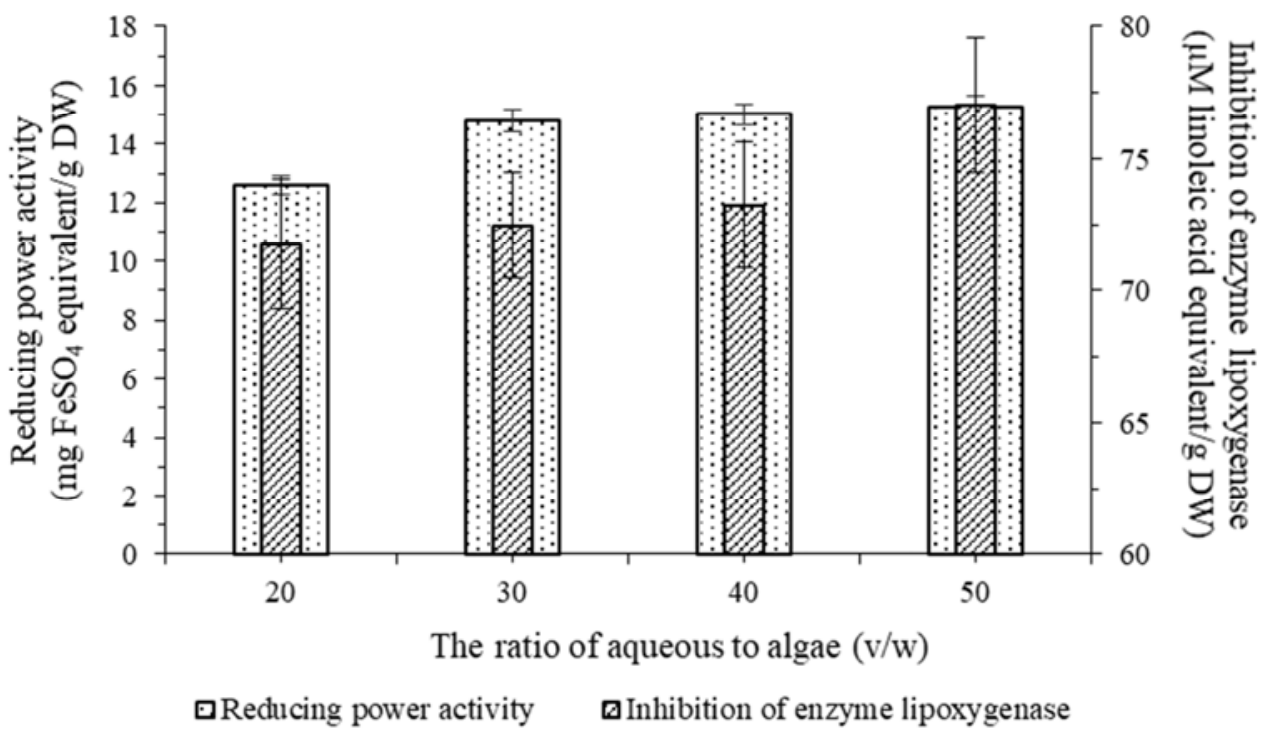

Figure 6. Effect of the solvent to algae ratio on reducing power activity and lipoxygenase enzyme inhibition activity.

\subsubsection{Effect of the Solvent $\mathrm{pH}$}

The difference in solvent $\mathrm{pH}$ caused the significant difference of laminarin content, antioxidant activity, and lipoxygenase inhibition $(\mathrm{p}<0.05)$. Laminarin content at solvent ( $\mathrm{pH}$ 2) was $74.09 \%$ and $61.35 \%$, compared to solvent $(\mathrm{pH}$ 9) and solvent $(\mathrm{pH} 7)$, corresponding to $7.35 \pm 0.26 \mathrm{mg}$ laminarin equivalent/g DW. Antioxidant activity and lipoxygenase inhibition activity got the highest value at solvent $(\mathrm{pH} 7)$ and the lowest value at solvent $(\mathrm{pH} 2)$
(Figure 7). The activity of total antioxidant, reducing power, and lipoxygenase inhibition was $11.96 \pm 0.42 \mathrm{mg}$ ascorbic acid equivalent/g DW, $9.84 \pm 0.37 \mathrm{mg} \mathrm{FeSO}_{4}$ equivalent/g $\mathrm{DW}$, and $50.39 \pm 1.85 \mu \mathrm{M}$ linoleic acid equivalent $/ \mathrm{g} \mathrm{DW}$ at solvent ( $\mathrm{pH} 2$ ), corresponding to $0.81 \%, 0.85 \%$, and $0.95 \%$ in comparison to solvent (pH 9) (Figure 8). The solvent $\mathrm{pH}$ using for the extraction of laminarin depended on brown algae species and laminarin structure, as in the notice of Shekhar et al. [1]. 


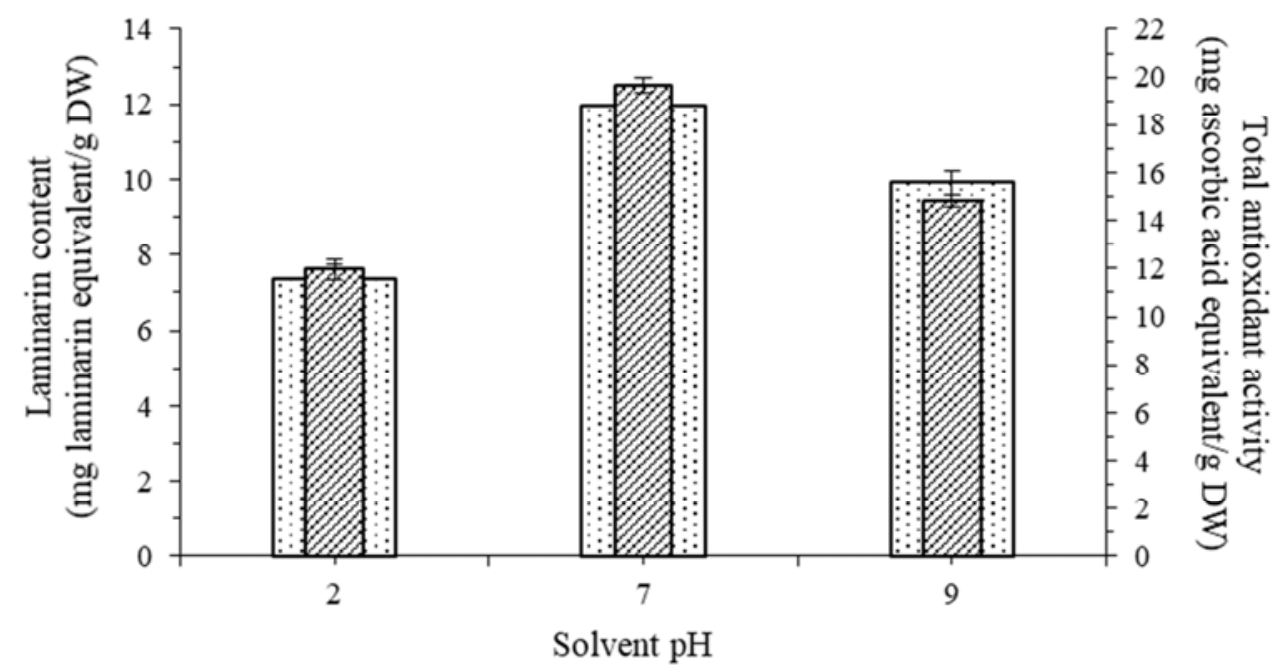

■Laminarin content $\square$ Total antioxidant activity

Figure 7. Effect of solvent $\mathrm{pH}$ on laminarin content and total antioxidant activity.

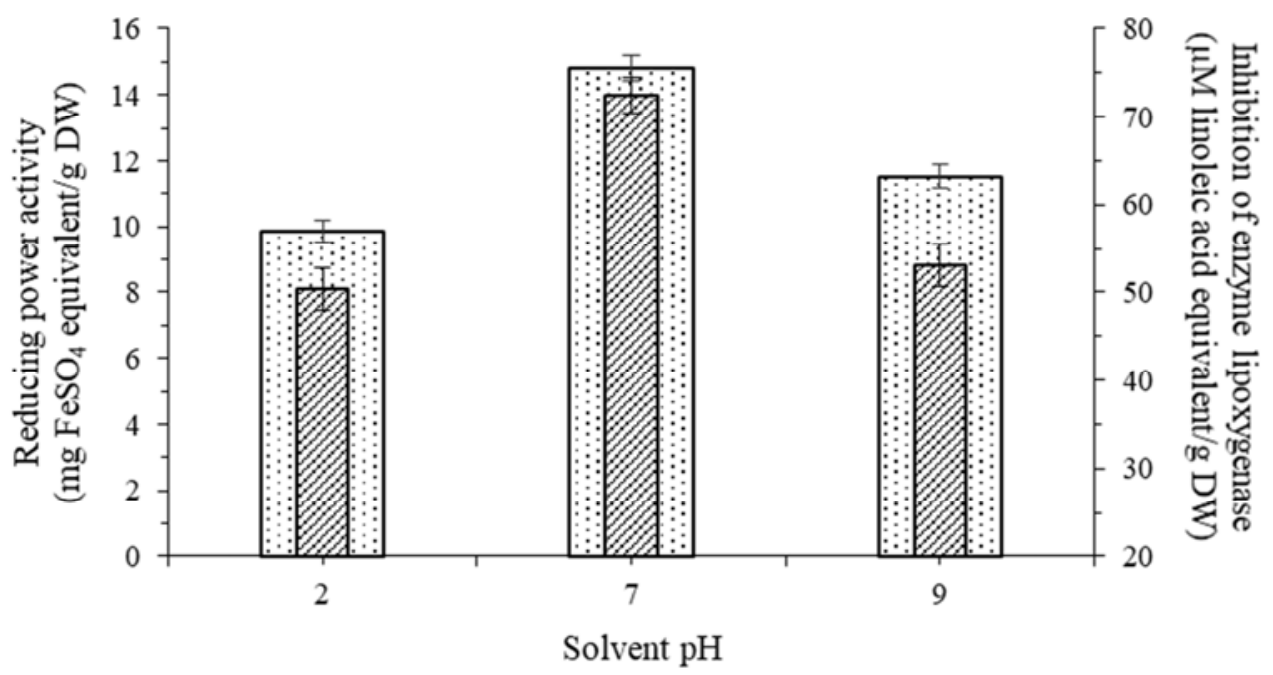

$\square$ Reducing power activity $\quad$ Inhibition of enzyme lipoxygenase

Figure 8. Effect of solvent pH on reducing power activity and lipoxygenase enzyme inhibition activity.

\subsection{Laminarin Characterization}

The average molecular weight and the viscosity of laminarin ware $505.18 \mathrm{kDa}$ and $14.17 \pm 0.29 \mathrm{cPs}$, respectively. The average molecular weight was lower than alginate. LC/MS spectrum showed 07 fragments in laminarin structure consisting of $292.0837,380.0946,481.6256,759.1812$, 962.2458, 1138.2717, and $1517.3714(\mathrm{~m} / \mathrm{z})$ (Figure 9). The sulfate content of laminarin $(48.72 \%)$ was higher than the notice of Chen-Feng [5]. The retention time was suitable to the notice of Spicer et al. on laminarin extracting from Laminariales and Fucales [11].

FTIR spectrum exhibited function groups of laminarin characterization, for example, characteristic absorption peak at $3427.67,1637.70,1038.33,1417.26,1237.34$, and 688.05, corresponding to the group of $\mathrm{O}-\mathrm{H}, \mathrm{C}=\mathrm{O}, \mathrm{C}-\mathrm{O},-\mathrm{C}-\mathrm{H}$, $-\mathrm{O}-\mathrm{SO}_{3}^{-}$, and $-\mathrm{CH}=\mathrm{CH}-(\mathrm{cis})$, respectively, that belonged to the vibration of $\mathrm{O}-\mathrm{H}$ stretching, the stretching of symmetry and asymmetry, $\mathrm{C}-\mathrm{O}$ stretching, $-\mathrm{C}-\mathrm{H}$ bending, $\mathrm{S} \equiv \mathrm{O}$ stretching, and $-\mathrm{CH}=\mathrm{CH}-(\mathrm{cis})$ bend. The characteristic absorption peak at 2922.60 and 2854.87 was the vibration of $\mathrm{C}-\mathrm{H}$ stretching belonging to $-\mathrm{CH}_{2}-$ group or $-\mathrm{CH}_{3}$ group (Figure 10). FTIR showed ring structures in laminarin molecular and stretching of different groups. The results exhibited the impact of the temperature, time, and physical chemistry factors caused by the change of chemistry characterization of laminarin. 


\section{Acquisition Parameter}
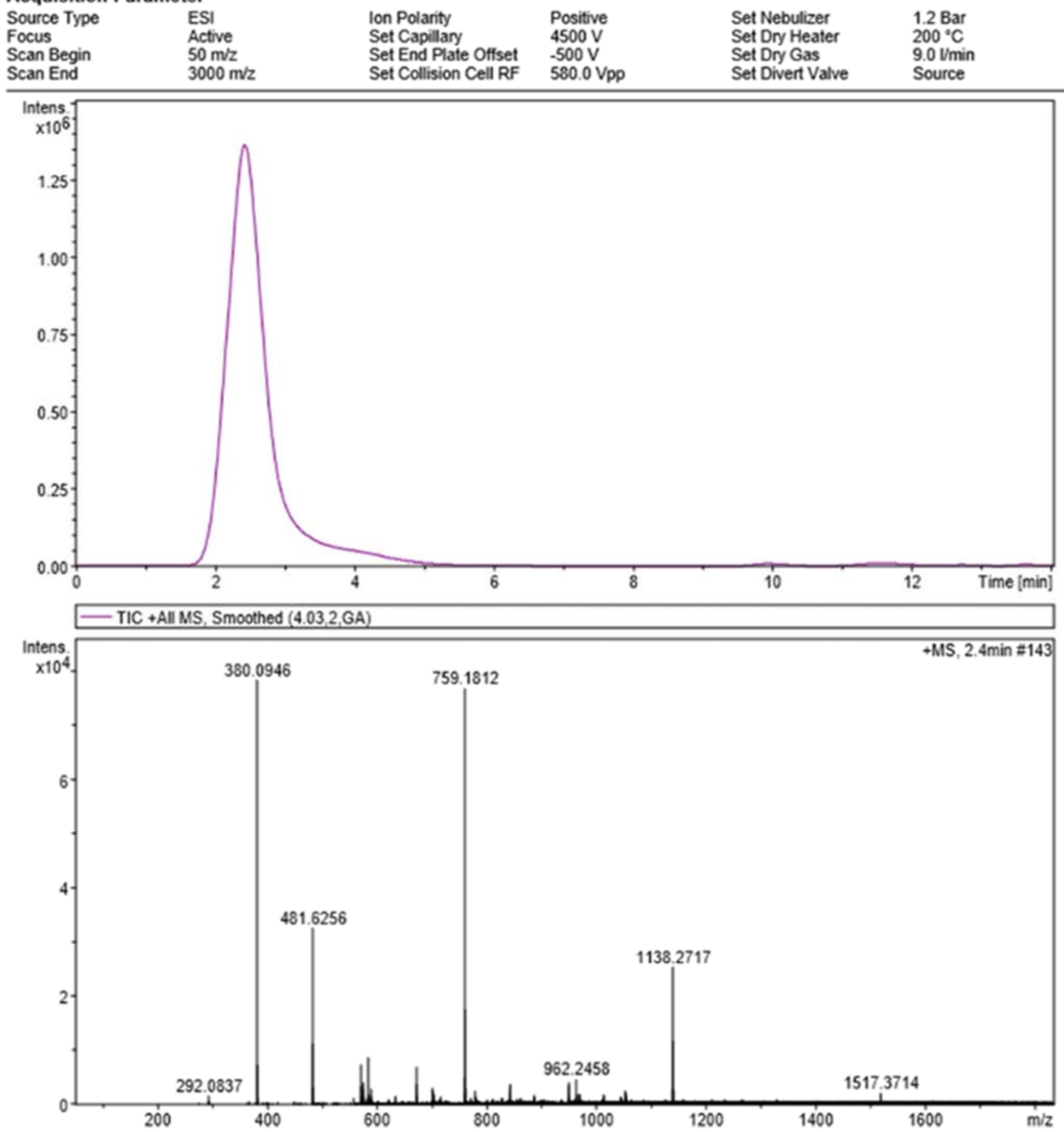

Figure 9. LC/MS spectrum of laminarin. 


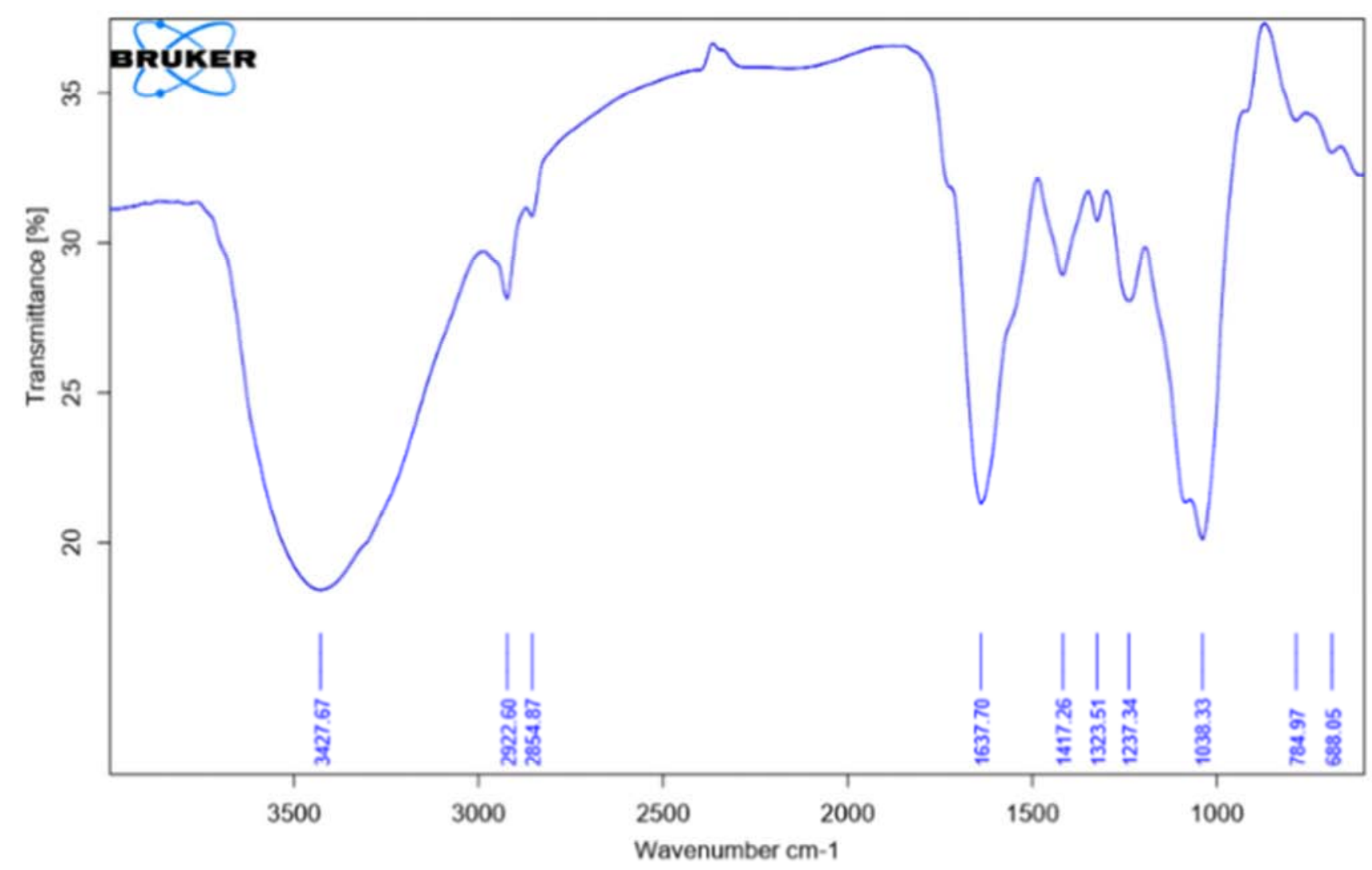

C.:OPUS_7.0.122MEASLaminarin.0 Laminarin Instrument type and / or accessory

Figure 10. FTIR spectrum of laminarin.

Table 1. Functional groups characterization of laminarin on FTIR spectrum

\begin{tabular}{|c|c|c|c|c|}
\hline \multirow{2}{*}{ Group } & \multirow{2}{*}{ Vibration } & \multicolumn{3}{|l|}{ Peak $\left(\mathrm{cm}^{-1}\right)$} \\
\hline & & Laminarin [5] & Laminarin sulfate [5] & Laminarin in the current study \\
\hline $\mathrm{O}-\mathrm{H}$ & The vibration of O-H stretching & 3370 & 3441 & 3427.67 \\
\hline$-\mathrm{CH}_{2-}$ & The vibration of $\mathrm{C}-\mathrm{H}$ stretching & 2924 & 2978 & $2922.60,2854.87$ \\
\hline $\mathrm{C}=\mathrm{O}$ & $\begin{array}{l}\text { The stretching vibration of } \\
\text { symmetry and asymmetry }\end{array}$ & 1641 & 1649 & 1637.70 \\
\hline $\mathrm{C}-\mathrm{O}$ & The vibration of C-O stretching & 1043,1076 & 1070 & 1038.33 \\
\hline$-\mathrm{C}-\mathrm{H}$ & $-\mathrm{C}-\mathrm{H}$ bending & $1453.36-1385.50 / \mathrm{cm}$ & & 1417.26 \\
\hline$-\mathrm{O}-\mathrm{SO}_{3-}$ & The vibration of $\mathrm{S} \equiv \mathrm{O}$ stretching & - & 1258 & 1237.34 \\
\hline$-\mathrm{O}-\mathrm{SO}_{3}-$ & The vibration of C-O-S stretching & - & 816 & \\
\hline$-\mathrm{CH}=\mathrm{CH}-(\mathrm{cis})$ & The bend of $-\mathrm{CH}=\mathrm{CH}-(\mathrm{cis})$ & & & 688.05 \\
\hline
\end{tabular}

The vibration of $-\mathrm{OH}$ stretching and $\mathrm{C}-\mathrm{H}$ stretching in $-\mathrm{CH}_{3}$ or $-\mathrm{CH}_{2}$ groups occurred at the peak of $3370 \mathrm{~cm}^{-1}$ and $2924 \mathrm{~cm}^{-1}$, respectively (Table 1). The stretching vibrations peaks of $\mathrm{S}=\mathrm{O}$ and $\mathrm{C}-\mathrm{O}-\mathrm{S}$ exhibited the sulfate groups in the sugar molecules of laminarin, for example, $1258 \mathrm{~cm}^{-1}$ and $816 \mathrm{~cm}^{-1}$, respectively.

\section{Conclusion}

Laminarin of brown algae Sargassum mcclurei grown commonly in Vietnam possessed antioxidant activity and lipoxygenase inhibition activity, got the highest value of
$11.98 \pm 0.49 \mathrm{mg}$ laminarin equivalent/g DW, $19.66 \pm 0.47 \mathrm{mg}$ ascorbic acid equivalent/g DW, $15.55 \pm 0.61 \mathrm{mg} \quad \mathrm{FeSO}_{4}$ equivalent/g DW, and 73.04 $\pm 2.53 \mu \mathrm{M}$ linoleic acid equivalent/g DW, respectively. The suitable condition of extraction for activity laminarin was at $90^{\circ} \mathrm{C}$ for 2 hours in aqueous $(\mathrm{pH} 7)$ with the aqueous to algae ratio of $40 / 1(\mathrm{v} / \mathrm{w})$. Laminarin had the average molecular weight and the viscosity corresponding to $505.18 \mathrm{kDa}$ and $14,17 \pm 0.29 \mathrm{cPs}$, respectively. Active laminarin composed of 7 fragments (292.0837, 380.0946, 481.6256, 759.1812, 962.2458, 1138.2717, and $1517.3714(\mathrm{~m} / \mathrm{z}))$ with sulfate content of $48.72 \%$. Laminarin of brown algae Sargassum mcclurei is a potential in the 
application into functional foods and pharmaceutics.

\section{Acknowledgements}

The author thanks Nha Trang Institute of Technology Application and Research and Vietnam Academy of Science and Technology for funding.

\section{References}

[1] Shekhar U. K., et al. (2015). Laminarin from Irish brown seaweeds Ascophyllum nodosum and Laminaria hyperborea: Ultrasound assisted extraction, characterization and bioactivity. Mar Drugs, 13 4270-4280.

[2] Angelika G., Wolfgang, R., Udo, K. and Ulf, K. (2016). Chemical characterization and quantification of the brown algal storage compound laminarin - A new methodological approach. J Appl Phycol, 28 (1): 533-543.

[3] Krawiec P., K, M. and S, I. (2016). The use of laminarin as an effective tool for anti-resistance management in chemical control of grey mould in raspberry. Acta horticulturae, 1133 (1133): 469-472.

[4] Song K., et al. (2017). Laminarin promotes anti-cancer immunity by the maturation of dendritic cells. Oncotarget, 8 (24): 38554-38567.
[5] Chen-Feng J., J, Y.-B. and M, D.-Y. (2013). Sulfated modification and anti-tumor activity of laminarin. Exp Ther Med, 6 (5): 1259-1264.

[6] Devillé C., Gharbi, M., Dandrifosse, G. and Peulen, O. (2007). Study on the effects of laminarin, a polysaccharide from seaweed, on gut characteristics. J Sci Food Agric, 87 $1717-1725$.

[7] Prieto P., Pineda, M. and Aguilar, M. (1999). Spectrophotometric quantitation of antioxidant capacity through the formation of a phosphomolybdenum complex: specific application to the determination of vitamin E. Anal Biochem, 269 (2): 337-341.

[8] Qin Y. Z., Robert, M. H., Jodi, L. E., Roberta, R. H. and Carl, L. K. (2002). Antioxidative activities of oolong tea. J Agric Food Chem, 50 (23): 6929-6934.

[9] Indu H. and Seenivasan, R. (2013). In vitro antioxidant activity of selected seaweeds from southeast coast of India. Int J Pharm Pharm Sci, 5 (2): 474-484.

[10] Poonam B., Cai-Yan, T., Jian-Ming, O. and Kai, Y. (2016). Repair effect of seaweed polysaccharides with different contents of sulfate group and molecular weights on damaged HK-2 cells. Polymers, 8 (5): 188-207.

[11] Spicer S., Adams, J., Thomas, D., Gallagher, J. and Winters, A. (2017). Novel rapid method for the characterisation of polymeric sugars from macroalgae. J Appl Phycol, 29 (3): 1507-1513. 